\section{Budget cuts: funding needed for startling new discoveries too}

UK research-funding bodies have reacted to paucity in their budgets with plans to focus on supporting just a handful of scientists (see, for example, Nature 465, 16-17; 2010); translational research; or research in areas of monetary importance, such as ageing. However, these strategies leave little room for surprising and groundbreaking discoveries.

Risk-averse funding panels hugely favour hypothesis-driven research because it is clear how results will be obtained and the issues resolved. Here, discovery is generally made after a specific search, such as for a test to indicate whether a particular protein is involved in a process. This is the right approach for uncovering the details behind a phenomenon that is already described.

But a totally unexpected discovery can be a hypothesisforming breakthrough. For example, when a novel process comes to light that is outside the framework of current understanding. Radioactivity and penicillin are among the seminal discoveries in this category. Findings akin to these should not be precluded by cuts in funding.

Investing in new technology such as super-resolution microscopy (see Nature 462, 675-678; 2009) could be one way to encourage explorative research. Daniel M. Davis Division of Cell and Molecular Biology, Sir Alexander Fleming Building, Imperial College London, London SW7 2AZ, UK e-mail:d.davis@imperial.ac.uk

\section{Budget cuts: leaven the curriculum with a pinch of research}

Diane Auer Jones suggests that cash-strapped US universities should reserve some faculty positions just for teaching
(Opinion, Nature 465, 32-33; 2010). But a university's power and efficiency comes from combining research and teaching. The best way to learn science is to do science.

Universities need teacherscholars who can incorporate the excitement of research into their classes and bring students into research projects to give them a sound understanding of scientific practice. This will widen and deepen the pool of talent for graduate school and benefit the teachers, doctors, lawyers, politicians, business leaders and citizens of the future.

Science as taught at US secondary schools is prone to emphasizing static, authoritative facts. Science in practice focuses on open questions, competing explanations and new discoveries. Undertaking research at university will seal this gap.

Peter A. Bednekoff Department of Biology, Eastern Michigan University, Ypsilanti, Michigan 49197, USA e-mail:pbednekof@emich.edu

\section{Budget cuts: company investment could help offset the shortfall}

Research should not be left just to the elite universities (Opinion, Nature 465, 32-33; 2010).

Take the public university where I teach, where research is important and cost-effective. The university produces the largest number of Hispanic doctorates in the United States. Because it is located in Miami, it has built a strong reputation for research on hurricanes, the Everglades and the coastal ecosystem in Florida, and on many different aspects of LatinAmerican and Caribbean affairs. Cutting our funding for research and development (R\&D) could set us back by decades.

One solution might be for big companies to contribute to a national funding pool to offset the loss of federal funding. These companies benefit hugely from US government R\&D money as a result of employing university graduates. By investing some of their profit into $R \& D$ in science, technology, arts, culture and other endeavours, they would be guaranteed a steady supply of highly skilled and cultured employees to increase their productivity and profit margins.

Non-profit associations such as the American Chemical Society have led the way in creating this type of reserve. It is time for our leading industries to become responsible shareholders in one of the world's largest intellectual democracies

Gautam Sen Department of Earth and Environment, College of Arts and Sciences, Florida International University, Miami, Florida 33199, USA e-mail: seng@fiu.edu

\section{Protection needed for international species collections}

The destruction of most of the zoological collection of the Butantan Institute in São Paulo, Brazil, by a fire on 15 May, will affect zoology worldwide (see Nature 465, 272; 2010). Safeguarding and financing such important collections, including those housed in facilities in developing countries, should be an international concern.

More than 80,000 preserved snakes and 500,000 arthropods were lost. Holdings included undescribed species, holotypes used to name species, testimony specimens and extinct animals, all gathered over the past 100 years, plus materials on loan from other institutions.

Institutions that house collections from around the world need to help guarantee the security of other valuable collections by decentralizing national taxonomic records, while maintaining respect for national autonomy. Supporting the creation of small local collections to provide regional records of the biota would generate information on a wider range of specimens.

Such a triple-redundancy system across international, national and regional collections would protect all this important information effectively.

The swift publication of knowledge relating to precious taxonomic collections remains a top priority.

\section{Eduardo Bessa Laboratório de} Ecologia Comportamental da Reprodução, Universidade do Estado de Mato Grosso, CP 287, Tangará da Serra, Mato Grosso 78300-000 Brazil

e-mail:prof.bessa@yahoo.com.br

\section{Environment groups are not to blame for public complacency}

It is an oversimplification to suggest that environmental groups have distanced themselves from the ordinary people whose interests they seek to serve (Column, Nature 465, 287; 2010). Environmental groups continue to work as hard as ever, but face an increasing challenge because environmental problems are beyond the scale of direct perception by individuals.

Fault, if any, lies mainly with the industrial groups. Although they ameliorate the most visible effects of their systematic global activities, they continue broadly with their unsustainable practices. Fundamental reform is needed.

Environmental advocacy groups are no more to blame for failing to resolve environmental problems than are the researchers who expose the problems. Neither group is to blame for public complacency. Nonetheless, both need to work at every level, from engaging those at the grass roots to informing those at the highest levels of policy and debate.

Kevin Matthews ArchitectureWeek, PO Box 1588, Eugene, Oregon, USA e-mail:matthews@artifice.com 